\title{
12. Genealogy and Derangement
}

\author{
John Docker
}

I am a cultural historian, which I feel gives me a licence to wander. Over the decades I have been interested in literary and cultural theory, popular culture, postmodernism and poststructuralism, monotheism and polytheism, diaspora, historiography, Jewish identity, and Gandhian non-violence. I have always written personally, mixing theory and analysis with life stories and family history, and am currently writing an ego-histoire, Growing Up Communist and Jewish in Bondi: Memoir of a non-Australian Australian. Since the mid1980s, I have written critiques of Zionist nationalism and settler colonialism, and reflected on partition in Palestine and India, and Martin Buber's idea of a bi-national Palestine. I have devoted the last several years to genocide and massacre studies, exploring Raphaël Lemkin's suggestion in his originating definition in 1944 that genocide is constitutively linked to settler colonialism (Docker 2008a, 2012b). My most recent books are The Origins of Violence: Religion, History and Genocide (Docker 2008b) and (with Ann Curthoys), Is History Fiction? (Docker \& Curthoys 2006).

As far back as I can recall, I have always thought it was and is completely wrong of a people to come from afar and take away another people's land and world. Its name is settler colonialism, and I am as passionately opposed to settler colonialism in Australia as in Palestine/Israel. Settler colonialism, genocide and massacres are entwined historical processes, by which all settler-colonists, including myself in Australia, have been advantaged. After such knowledge, how can one talk of belonging? Why should we not feel guilt and shame?

I agree with Pierre Nora in 'L'Ego-Histoire est-elle Possible?' that the I who writes ego-histoire will always be enlivened and inspired by failure, the failure of the ego-historian to possess a single coherent successfully positive identity, the failure of the texts we produce to possess a single generic character (Nora 2001). The ego-historian and ego-historical text are always off-balance, always close to vertigo and derangement. Genre in ego-histoire tosses about like a drunken boat, to adapt a famous image of Rimbaud, an important figure for my 1960s generation who appreciated his sentiment in a letter of 1871 that we strive to reach 'the unknown by the derangement of all the senses' (Il s'agit d'arriver à l'inconnu par le dérèglement de tous les sens) (Rimbaud 2005, pp. 370-371). 


\section{Diaspora and Identity}

I will follow ego-histoire's methodological suggestion that personal and family histories are interventions into contemporary history; they are both intensive and lead outwards to wider perspectives (Curthoys A, 2012). Je est un autre, said Rimbaud in the same letter, I is someone else (Rimbaud 2005, pp. 370-371). I am an other, or others. My father and mother gifted me wildly divergent diasporic family histories, Protestant Irish and London Jewish. My father's mother, Susan Nash, from a Protestant family in County Clare, on the west coast of Ireland, migrated to Australia in 1881. In Sydney, Susan Nash established an Anglican, English monarchy-loving family, from which my father, as a young carpenter, born in 1894, rebelled to become part of the political left for the rest of his life. As a young man he was in the IWW, the anarchist and syndicalist Industrial Workers of the World, the notorious or wonderful Wobblies, destroyed by the state during the First World War. In 1920 he became a foundation member of the Communist Party of Australia. Over the next three decades he occupied high positions in the Party, in the Central Committee and also the Political Committee, a kind of inspectorate responsible for trouble-shooting within the Party and also for expulsions from it, of which more soon.

As I record in my 1492: The poetics of diaspora, my mother Elsie Levy and her Jewish family migrated from the East End of London in 1926 (Docker 2001, pp. 20-33). My mother, born in 1912, was then 14. At some time in the 1930s this young woman Elsie Levy became a political radical and joined a Jewish branch of the Communist Party, along with her two younger brothers, Lew Levy and Jock Levy; the two brothers and my mother then helped form a Jewish Youth Theatre, where, in Lew's words, 'We played and read Sholom Aleichem, [Isaac Leib] Peretz and Israel Zangwill'. (Peretz, 1851-1915, was a Polish-Jewish author who wrote in Yiddish; Zangwill, 1864-1926, was an Anglo-Jewish writer; of Sholom Aleichem, 1859-1916, more later.) Jock Levy would become an important figure in Australian radical theatre and film history, in the latter 1930s acting and directing in the Jewish Youth Theatre and later in the New Theatre and then the Waterside Workers' Federation Film Unit in the 1950s (Docker 2001, pp. 164-167; Milner 2003, p. 42).

In 1941 my mother and father married in Bondi, Sydney, my father being many years older and widely travelled, including attending in Moscow in 1935 the Comintern's Seventh Congress and the International Lenin School. My mother brought to their relationship her specific history as an inheritor of longstanding Jewish dissident traditions, with her own international and diasporic consciousness, committed to Jewishness as an ethical universalism, 
intensely aware of what was happening to Jews all over the world, especially in the 1930s in relation to the rise of fascism, including in her own 'diasporic home' in England.

As I see it, my father and mother met in deeply troubled times in a world communist movement that was a kind of commodious cosmopolitan tent. In this essay I wish to think about how growing up in a communist family committed to internationalism and opposed to nationalism and racism may have influenced my writings from the New Left 1960s onwards, including my critiques of Zionism.

As befits ego-histoire with its strong archival interests, I think about what my parents have left me, in books, pamphlets, documents, letters, photos, memories. From these textual sources I try to imagine what my parents were like before I was born in 1945, for their histories, separate and together, have informed my upbringing. In this essay I talk about both my father and mother, though to write about my mother is a challenge. I haven't even a photo of her when she was young. How I wish I had a photo of her, or a diary, or letters she might have written during that time.

As it has turned out, however, I do have some reading material of hers. Stretching from the 1930s into the 1960s, they consist of three books, a pamphlet, and an inner Australian Communist Party document. I will focus on one of the books, William Zukerman's The Jew in Revolt: The Modern Jew in the World Crisis (Zuckerman 1937), which she must have acquired when she was still Elsie Levy living with her parents in Bondi.

I admire Walter Benjamin's insight, in his well-known essay 'Unpacking my Library: A talk about book collecting', that to a 'true collector the acquisition of an old book is its rebirth'. After World War Two, Hannah Arendt chose the essay, originally published in 1929, as the opening chapter of Illuminations (Benjamin 2007, pp. 61, 66).

My mother, born in 1912, and Hannah Arendt, born in 1906, were of the same generation; my mother married a communist and non-Jew, Ted Docker, and Hannah Arendt married a communist and non-Jew, Heinrich Blücher (Kohler 1996). References to Arendt will be like a silken thread throughout the essay; Arendt as part of a long post-Enlightenment tradition of liberal Judaism (Curthoys, 2013). 


\section{My Father, Ted Docker: From the IWW to the Communist Party}

Here I must record some contradictory reflections on my father, including, perhaps inevitably, conflicting views of the Soviet Union, which from 1920 till he died was central to his life. Just as my father rebelled against his family's legacy of values, in my late teenage years I rebelled against certain features of his legacy - but not, I think, all. There are continuities as well as discontinuities in historical passages from the IWW to the Communist Party to the New Left of the 1960s and 1970s.

The main continuity concerns anti-racism and anti-nationalism, which early-twentieth century radical groups inherited from nineteenth-century anarchist and socialist movements. Internationalism features in historians' accounts of the IWW. Verity Burgmann points out that the IWW's striving for the One Big Union would not be complete without the workers of all nationalities and races. The IWW consistently opposed the White Australia policy (Burgmann 1995, pp. 79-91).

There is a striking degree of continuity between the IWW and the Communist Party from 1920 in terms of internationalism and opposition to racism and nationalism. I think this continuity is evident in my father's attitudes and actions. In the early 1970s Ann Curthoys and I persuaded my father to write about memorable episodes in his life, and we were especially struck by his vivid reminiscences of the Kalgoorlie Riots of 1934, a shameful episode in Australian labour history, in some ways, if in far more minor key, sharing features of a pogrom as in Kristallnacht in Germany in 1938, and also anticipating the anti-Lebanese race riots in Cronulla in southern Sydney in 2005. My father's reminiscence, 'The 1934 Kalgoorlie Riots', was later published in Labour History (Docker \& Gerritsen 1976, pp. 78-82). I'll reprise it here.

My father begins by saying that, as a member of the Political Committee, he was sent to Western Australia to investigate 'differences in the Yugoslav branch' in Kalgoorlie, 'which had two factions'. My father was given the task of restoring unity to the Yugoslav branch, but when he arrived in Kalgoorlie on 27 January, 1934 he had no opportunity to contact them as the riots started that same day. 'The death of the young Australian Jordon [Jordan]', wrote my father, 'precipitated the explosion'. He attended a meeting of the miners, held in a hall in Kalgoorlie, where the 'main complaint of the Australian workers', repeatedly made, was that 'their sons couldn't get jobs, but foreign-born workers could'. The 'Australian workers' sacked and set fire to buildings in Kalgoorlie, those identified as belonging to 'foreign shopkeepers', and then crowded on trains to travel to the nearby town of Boulder in order to continue the riots, which lasted 
for two days. In Boulder, a lorry was stationed on top of a hill by the miners' union officials in charge, with a crowd numbering in the 'thousands (but no women)'. My father says that 'two comrades who were young miners (one only about 20)' had helped him get out a roneoed leaflet which he'd written, and he gave them out to the miners as they walked up the hill towards the lorry. At the meeting speakers 'attacked the mining companies for employing so many foreigners, while Australians were unemployed'. My father continues:

The tone of the speakers was very racist. We decided that one of us should mount the lorry and strive to change the direction of the discussion to the following. Opposition should be directed against the mine-owners over wages and conditions. A log of claims had been presented to the owners, who had not given their consent. This should be our main attack, and to achieve these demands the unity of all workers irrespective of race is needed.

I mounted the lorry but it was considered unwise for me to attempt to speak, because I was not a miner, and I was unknown to the gathering.

I jumped up on top of the lorry and stood there; the oldest of the two comrades jumped up and addressed the crowd. He put forward the correct position and was well received.

There is a warm portrait of Ted Docker in Katharine Susannah Prichard's Winged Seeds, published in 1950. A sympathetic character, Dinny, relates of the Kalgoorlie riots that 'a little bloke name of Docker' and Tom, a local Party member, were 'out all that night, helpin' foreign women and children to get away from their burning houses' (Prichard 1984, pp. 30-31).

The main discontinuity between the IWW and the Communist Party concerns a historic choice for radicals in the twentieth century, between political cultures, between anarchist and libertarian thinking and activity on the one hand, and on the other the highly structured political organisation associated with MarxismLeninism and loyalty to the Soviet Union. When the IWW was defeated in 1917, it must have seemed clear to many radicals such as my father that what was now historically needed was the kind of hierarchical and tightly organised party whose model was provided by Lenin's Bolshevik revolution, creating the Soviet Union, the first society in history successfully to overthrow capitalism. Only a tightly organised Communist Party could survive destructive persecution by the state, including in illegal periods. The Marxist-Leninist model of a tightly organised party necessitated, however, a culture of internal policing and expulsion, especially as it turned out of intellectuals and writers. My father, I recall, said more than once when I was young that intellectuals could not be trusted in a revolutionary situation, they had no fixed class position and so 
could always waver. And, indeed, in the historical literature on the Australian Communist Party, my father's hostility to anyone who disagreed with the 'correct line' the Party prescribed at any one time, especially when exhibited by intellectuals and writers, has become almost legendary (Macintyre 1998, pp. 164, 178; Ferrier 1999, pp. 2, 66; Sparrow 2007, pp. 247-253).

Here was an acute difficulty for me, since in my late-teenage years as an English literature student at Sydney University I was becoming part of the very intelligentsia my father distrusted as historical betrayers of the working class. It pains me to recall my Oedipal harshness when my father and I, in the small Bondi flat, would have arguments about the Soviet Union. I felt impelled to point out that Stalin put people in forced labour camps, and would shout: 'Stalin killed people! How can you defend someone who killed people?' (Docker 1984a, pp. 77-81) How depressing it must have been for my father to register that his son who he hoped would be his heir as a revolutionary was rebelling against him and all his generation stood for. Further, my father, a very ascetic man, didn't drink or smoke (or own a car or house), and yet here was his son coming home late at nights on weekends in a state of disrepair.

Yet my father, I know from family stories, had rebelled against his father, indeed to such an extent that to my knowledge he never once mentioned or talked about him. I was repeating a father/son generational pattern. I was on my way to becoming an intellectual parricide, an activity in which, I have to confess, I became a repeat offender.

Looking back now, I think my bouts of late-teenage and early-20s drunkenness related to what Rimbaud's phrases and images suggested, where drinking myself silly was perhaps the rough equivalent of Rimbaud saying that to find the unknown we must derange ourselves. The unknown was a future as an intellectual outside my father's framework of values. Pierre Nora suggests in 'L'Ego-Histoire est-elle Possible?' that ego-histoire exists unresolvably between the social and the psychoanalytic, and here I will attempt some uncomfortable self-psychoanalysis, or at least a jittery journey into self-reflexivity. I recall a friend once visiting in the late-1980s and saying with commendable frankness, something like: 'We know what you're like, John; you like something and then suddenly you turn against it, why?' Challenged by ego-histoire, I'll attempt an uncertain answer here.

In learning to become a Leavisite literary critic in my student years, yearning for the supposed finer cultures of the pre-industrial English past, I was trying to displace my Marxist father, with his overriding interest in the political and economic and faith in the Soviet Union, with a critical father, F. R. Leavis, and a new belief system. Yet the infatuation with being a Leavisite did not last. I turned sharply, satirically, almost savagely, against Leavis's kind of criticism, 
as I recorded in a later essay, 'How I Became a Teenage Leavisite and Lived to Tell the Tale', first published in Meanjin in 1981 (Docker 1981) and then as the prologue to my In a Critical Condition in 1984 (Docker 1984b). Much of my intellectual life has involved a very similar repetition-compulsion, attraction to an intellectual interest or approach or figure followed a few years later by sharp critique and disengagement: the Sydney Libertarians, Derrida, popular culture, Australian literature (Docker 1972, pp.40-47; 1998, pp. 24-28; 2007, pp. 263-290).

Looking back at a strange life, I would have to say that I'm considerably less than sane.

Yet, I now think, my father's legacy is surely mixed. I rebelled against his particular optimism about history, his utopian certainty that the Soviet Union would become humanity's future; yet perhaps I've always also retained an intense optimistic desire, almost messianically enthusing about postmodernism or Mikhail Bakhtin's notions of carnival and carnivalesque. Yet, disengaging, I'm also often drawn to pessimism, dystopian visions, melancholia, concerning the idiocies, cruelties and absurdities of history; humanity as a species given to genocide and massacre; or finding myself in the Australian society I live in.

In political terms, I rebelled against a centralised, authoritarian Communist Party, attracted for a while to the Sydney Libertarians and becoming part of a New Left intelligentsia whose anti-hierarchy, anarchism and pluralism was a kind of theatrical Dadaist reprise of the IWW (see Sparrow 2007, p. 290). I didn't and don't wish to join any political party, nor indeed any organisation, even once declining to join an organisation for independent scholars. I can't 'join'. The cultural theorists I enduringly like, Mikhail Bakhtin and Walter Benjamin, are also as it were non-joiners. In their biography Mikhail Bakhtin, Katerina Clark and Michael Holquist create a portrait of an intellectual personality who in effect disliked being agreed with (Clark \& Holquist 1984, p. 2). Hannah Arendt writes in the introduction to Illuminations that in her view Benjamin during the 1920s and 1930s was never going to commit himself, however tempted, either to Zionism or to joining the Communist Party, given his 'bitter insight that all solutions ... would lead him personally to a false salvation, no matter whether that salvation was labeled Moscow or Jerusalem' (Arendt 2007, p. 36).

Nonetheless, I think I have inherited from my father his internationalism and anti-racism and perhaps also a certain fierceness, a willingness to overturn critical institutions and theories just as he was willing to defy the racist Australian workers about to attack Yugoslavs and Italians in Kalgoorlie in 1934. I hope so. Of course, it is that same ill-mannered truculence that ensured I would become an academic failure. But then, as Pierre Nora ponders in 'L'ego-histoire est-elle possible?', failure is intrinsic to ego-histoire. 


\section{My Mother, Elsie Levy: A Diaspora Consciousness}

In 1937 in Bondi in a semi-detached house which I would later know as my grandparents' home, a 25-year-old woman, Elsie Levy, was reading William Zukerman's The Jew in Revolt: The modern Jew in the world crisis, published in London (Zukerman 1937). Now I think: why was she reading this book? What did it mean to her? Did she agree with it? Who in Zukerman's view was the Modern Jew? What would she have read in The Jew in Revolt concerning the Palestinians? That she had kept it all the subsequent years of her life must mean it was important to her, and that she hoped one day it would be read again in her family.

I'd never heard of William Zukerman. I looked up Elizabeth Young-Bruehl's biography, Hannah Arendt: For love of the world, which tells us that Zukerman was the editor of the Jewish Newsletter, which he had begun in 1948, and was an outspoken organ of dissent within the American Jewish community. He was a disciple of Judah Magnes, and he knew that Arendt also admired Magnes, as she had made clear in a eulogy for him on his death in 1948 (Young-Bruehl 2004, pp. 290-291; Zukerman 1964). Now I had some bearings. Judah Magnes (18771948), a founder and first president of the Hebrew University in Jerusalem, was an associate of the philosopher Martin Buber. In their view, Zionism was not a political movement but primarily spiritual and cultural. Buber believed that the land of Palestine should be shared between its indigenous people and the incoming Jews from Europe; there could be autonomous Arab and Jewish communities living amicably together and cooperating in the one bi-national state (Docker 2013, pp. 86-116; Mendes-Flohr 1983, pp.112, 148-149, YoungBruehl 2004, pp. 225-227).

Perhaps Elsie Levy had acquired Zukerman's red-covered 1937 book because she already knew of Zukerman and was enjoying reading and talking about articles he was writing for Harpers Magazine with other young, eastern suburbs radicals in Sydney in her circle of friends, including in the Jewish Youth Theatre. What she could ponder in The Jew in Revolt were the book's very strong likes and dislikes, in relation both to the impact of Hitler and Nazism on Europe, and political Zionism in Germany as well as Palestine. The Jew in Revolt is rich in arguments, attitudes, predictions and prophecies.

Zukerman was particularly apprehensive about the rise of nationalism in the 1920s and 1930s, and nationalism's ways of attaining, or attempting to attain state power. Here he puts forward what we might call the Zukerman thesis concerning the nexus of nationalism and anti-Semitism so visible in fascism and Nazism. Their anti-Semitism is not, he believes, a simple continuation of 
previous outbursts of anti-Semitism in European history, during the Crusades and the Inquisition (Zukerman 1937, pp. 19-22). In my mother's copy, there is a line in the margin next to Zukerman's argument that what is historically new is that the Nazis have made anti-Semitism 'the chief tool with which they have hewed their way to power'. Zukerman then contends that such a political use of anti-Semitism has become 'the feature of Nazism that is most widely imitated abroad', not only in countries of Eastern and South-Eastern Europe such as Poland and Romania but in the Western democratic countries of Europe, in France, Belgium and England (Zukerman 1937, pp. 23-24, 29-31, 34-38).

In an analysis that must surely have interested my mother, Zukerman writes that in England 'anti-Semitism has become the chief if not the only programme of British fascists', with 'vile anti-Semitic meetings' and 'anti-Jewish demonstrations in the East End of London and other thickly populated Jewish districts'. Mosley's speeches are 'tirades against the Jews, full of bitterness and hatred as though he had been a pupil of Julius Streicher all his life'; and there is a 'streak of sadism' in these speeches and those of his lieutenants 'which is actually frightening' (Zukerman 1937, pp. 39-41).

Yet, and here is part of his thesis, Zukerman feels there is a kind of historical hope in the way the fascists and Nazis have identified themselves so completely with anti-Semitism, for the struggle against fascism and Nazism by the liberal democratic world must also mean a simultaneous fight against anti-Semitism. If fascism and Nazism can be defeated, Zukerman predicts, anti-Semitism also will be defeated (Zukerman 1937, pp.42-48). We are, says Zukerman, in the midst of a battlefield, the 'new Armageddon'. However, and here is Zukerman's prophecy, when the 'final battle of Armageddon is over', anti-Semitism is bound to be defeated: 'If democracy is to live, anti-Semitism must perish. Fascism itself has made the destruction of Jew-baiting a condition for the survival of civilization' (Zukerman 1937, pp. 49-51).

My mother would surely also have been intensely interested in what Zukerman thought about Zionism, as controversial an issue in the 1930s as it is in the contemporary world. In The Jew in Revolt, Zukerman is highly critical of Zionism when it associates itself with nationalism. In the spirit of Martin Buber and Judah Magnes, he makes a sharp distinction between political Zionism which enshrines nationalism, and what he considers to be true Zionism, which is cultural and spiritual, emphasizing agriculture and productive labour. For Zukerman, true Zionism, all that is 'attractive, sympathetic and great in the movement', was brought to Palestine in the late-nineteenth century by Russian Jews escaping persecution by the state as well as fleeing the Ghetto itself. The 'first Jewish settlers in Palestine' in the 1880s were imbued with the 'great social, moral and idealistic tendencies' which were fermenting in pre-Revolutionary Russian society at that time, an idealism they shared with 
the general Russian intelligentsia; this was the 'age of Tolstoy' when Russian humanitarians 'sought various escapes from industrial civilisation and its evils' (Zukerman 1937, pp. 139-141).

Zukerman regards the Zionism initiated by Herzl in the 1890s, with its 'political schemes' and 'nationalistic sentiments', as a betrayal of true Zionism. He is astonished by the manifestations of political Zionism in Germany, from 1933 onwards, for it not only shares much with Nazism in terms of ideas but also actively co-operates with the Nazi regime. Incredibly, Zukerman observes, the Nazi plan of a 'Jewish exodus' has found favour and support in the Zionist movement. In Nazi Germany the Nazis have shown a 'remarkable readiness to work together with the Zionists in this particular enterprise', the emigration of Jews to Palestine. The Zionist Organisation is the 'only political party' other than the Nazi which is permitted in Germany; Zionist newspapers are 'flourishing'; Zionist meetings are 'encouraged' while meetings of non-Zionist Jews, even of the 'Jewish ex-soldiers', are 'suppressed' (Zukerman 1937, pp. 110-114, 117, 141).

The chief Jewish promoters of the scheme of exodus and of 'partnership' with the Nazis, Zukerman writes scornfully, are the 'extremist Zionist-Revisionists who represent the nearest organised approach to fascism made by Jews as a body'. Zukerman is scathing of the behaviour of the Revisionists, led by Vladimir Jabotinsky, in Palestine in the 1930s, where they functioned as a 'fascist party', with 'Brown Shirts, Storm Troops, and all the paraphernalia of fascism'. The Revisionists hounded out from the Zionist movement 'every Liberal and Labour leader', while in 1933 they assassinated the 'able Zionist Labour leader, Dr Chaim Arlosoroff'. They spoke openly of 'transferring the several hundred thousand Palestine Arabs' to Arab States and of 'establishing a Jewish State' on both sides of the Jordan (Zukerman 1937, pp. 113, 116, 127, 155, 161, 172-173).

Nevertheless, Zukerman believes that from 1933 onwards, with the assassination of Dr Arlosoroff, moderate Zionists have turned against the Revisionists: 'Revisionism in all its manifestations is dead in the Zionist world'. By the middle of the 1930s, Zukerman is sure, Palestine's Zionists are returning to true Zionism (Zukerman 1937, pp. 174-176, 179, 205).

I can only speculate on what Elsie Levy thought of The Jew in Revolt. She would most likely have been very interested in Zukerman's ideal of the modern Jew, who has 'tended mostly towards the radical political parties' and brought to them 'enthusiasm, genius and devotion'. There is now, he writes in his eloquent conclusion, a Jewish trend towards 'social radicalism', a 'turning leftward' especially by young Jews in Europe and 'even in the United States' (and even in Australia, she might have thought to herself). In more general terms, Zukerman reflects, a revolt, moral, spiritual, social and economic, is observable amongst 
the mass of Jewish people against the 'economic evils of Capitalism', nourishing a 'Social-Revolutionary movement' that is opposed to 'racial and nationalistic' incitements (Zukerman 1937, pp. 250-254).

Yet Elsie Levy could also have reflected that Zukerman's book gives ground for fear as well as hope; fear that nationalism might overpower the cultural values he admires. Zukerman believes that in Palestine the Zionist trade union body Histadruth is torn between two loyalties, of international labour as against 'nationalistic Jewry', and that nationalism always 'proved the stronger', for example, in Histadruth conducting 'strikes against the employment of Arabs in Jewish enterprises' (Zukerman 1937, pp. 179-181, 185). He writes scornfully that the political Zionists in general refuse any 'social and intellectual contact' with the Arabs, based on 'human equality and friendship' (Zukerman 1937, pp. 162-164).

As the years went on, during the perilous time of World War Two and later, my mother would have observed the fate of Zukerman's predictions and prophecies. Zukerman's thesis, that when the democratic forces defeat fascism and Nazism, 'anti-Semitism is bound to be crushed' as well (Zukerman 1937, p. 50), was supported by Hannah Arendt in her 1944 essay 'New Leaders Arise in Europe'. Here Arendt hails the development of a militant Jewish underground movement against the Nazis, saying that it was only possible because William Zukerman was right ('one lonely preacher in the wilderness'), there has indeed been a 'fast disappearance of antisemitism all over the European continent'; were it not for this, she adds, 'a Jewish underground movement, Jewish fighting units, and so forth would never have come into existence' (Kohn \& Feldman 2007, p. 256).

Elsie Levy could well, however, have begun to suspect Zukerman's confident claim that from 1933 onwards, with the assassination of Dr Arlosoroff, Revisionism 'in all its manifestations is dead in the Zionist world' (Zukerman 1937, p. 205). On 4 December, 1948, when Menachem Begin, who inherited Jabotinsky's Revisionist ideals and would one day become prime minister of Israel, visited the United States to gain support for his newly formed Freedom Party, an open letter of protest was published in the New York Times. Drafted by Hannah Arendt and co-signed by her, Albert Einstein and others, it pointed out that while Begin's party now presents itself as a party of freedom, democracy, and anti-imperialism, it betrays its true character by its actions, as in the massacre of the Arab village of Deir Yassin earlier in 1948 (Arendt, Einstein et al. 2007, pp. 417-419; Young-Bruehl 2004, p. 232). Zukerman's prophecy here was proving increasingly wrong.

Zukerman's claim in The Jew in Revolt that there was active cooperation and partnership between the Zionists and the Nazis became a motif in Hannah Arendt's 1963 book, Eichmann in Jerusalem: A report on the banality of evil. Arendt points out that in the trial of Eichmann, the prosecution, fearing its 
case against him would be weakened, was careful not to bring into the open the 'cooperation' of the Jewish leaders throughout Nazi occupied Europe in the Final Solution. Eichmann received such cooperation 'to a truly extraordinary degree', with 'Jewish help in administrative and police work', including the 'final rounding up of Jews in Berlin' being done 'entirely by Jewish police' (Arendt 2006, pp. 42, 116-120, 125, 132, 143, 199).

Arendt's comment on the whole story of collaboration and betrayal by one's own resonates with pathos and horror: 'To a Jew this role of the Jewish leaders in the destruction of their own people is undoubtedly the darkest chapter of the whole dark story' (Arendt 2006, p. 117). What my mother thought of Arendt's Eichmann in Jerusalem, which caused a worldwide controversy when it came out, I don't know. My feeling is that she would have agreed with Arendt's view that many more Jews died because the recognised Jewish leaders enforced passivity by cooperating with the Nazis, and many more Jews would have lived if they had 'really been unorganised and leaderless' and had gone underground: 'there would have been chaos and plenty of misery but the total number of victims would hardly have been between four and a half and six million people' (Arendt 2006, p. 125). ${ }^{1}$

\section{Conclusion}

When I was a child and teenager, my mother would fondly recall her childhood in the East End, frequently staying with her grandmother nearby especially when her father the family patriarch became too dictatorial. She would also recall anti-Semitism, in the way a primary school teacher in her London school 'would pronounce my name, Levy', and she would refer to how disgusting Oswald Mosley the English fascist leader was, but would then comment that 'we' in the East End would not let him and his Blackshirts in to destroy our community. I was always puzzled by the way she would say 'we in the East End in the 1930s', as if she still lived not in Sydney but in faraway London. I was, of course, being obtuse. It took me a while to realise that in diaspora consciousness, as I note in the preface to my 1492: The poetics of diaspora, time and space are doubled (Docker 2001). Diaspora consciousness inheres in a sense of relating to more than one history, to more than one time and place, more than one past and future.

My mother's legacy has proven very powerful for me, in terms of diasporic consciousness, historical consciousness, my becoming a literary and cultural critic, and, from early adulthood, opposition to Zionism. I can't recall my father

\footnotetext{
1 See also Part IV of Hannah Arendt: The Jewish writings, for example, “"The Formidable Dr. Robinson": A Reply by Hannah Arendt' (Kohn \& Feldman 2007, pp. 496-511); also Zertal 2011, pp. 136-139.
} 
ever reading anything except political texts. I admired my uncles for their intense cultural interests and passionate arguing over ideas, and my uncle Jock for his lifelong association with theatre and film. I've always been drawn to a sense of the world as theatricality, the theatrum mundi, as Walter Benjamin wrote in 'The Storyteller' (Benjamin 2007, pp. 106). Growing up, my mother left me a precious memory related to her reading, that she loved the stories of Sholom Aleichem, the Russian and then American Jewish writer (think Fiddler on the Roof); an interest I can now trace back to the 1930s and the Jewish Youth Theatre.

If my father revealed a straightforward optimism about history centred in the Soviet Union, my mother's legacy provided a more divided, ambivalent historical consciousness; history as optimism also in belonging to the Communist Party and fealty to the Soviet Union, and yet history also as shadowed by danger, fear, betrayal, and catastrophe. I've always remembered my mother saying how much she liked Sholom Aleichem, but I never got around to reading his stories; I felt a slight prejudice against Aleichem as possibly a writer of simple comical tales. I have begun to read him now, and have been surprised by how disturbing they are. 'The Haunted Tailor', for example, creates a portrait of extreme poverty for the Russian Jews in the village of Zolodievka, where the story's main character Shimon-Eli lives: 'the moon gazed down at Zolodievka's gloomy half-ruined houses that stood squeezed together without courtyards or fences or trees, looking for all the world like a cemetery ... they were bowed so perilously that they would long ago have toppled over if they had not been propped up'. The tailor seeks to please his wife by buying a milking goat at another village, but the goat appears to be a golem, a possessed creature, a demon, changing its gender from female to male and back to female, bringing ridicule to the tailor, who by the end drifts into a catatonic state of madness, disintegration, near death (Howe \& Wisse 1979, pp. 2-36). ${ }^{2}$ On reading this story, I thought, here I am reading a text of an author admired by my mother that brings to mind Rimbaud's phrases about 'derangement of all the senses'.

In her 1943 essay, 'We Refugees', Hannah Arendt admires a Jewish tradition of 'Heine, Rahel Varnhagen, Sholom Aleichem, of Bernard Lazare, Franz Kafka, or even Charlie Chaplin', who prefer the status of conscious pariah (Kohn \& Feldman 2007, pp. 274, 275-297).

Growing up, I can't remember my mother ever saying anything about Zionism or Israel. When, however, Ann Curthoys and I were living in London in the early 1970s, my mother sent a letter, dated 2 October, 1973, which included the interesting sentences: 'It looks as if the Israeli Arab War is going to be a long

2 In their introduction to The Best of Sholom Aleichem, Irving Howe and Ruth R. Wisse relate that in reading Aleichem's stories they are drawn to a modernist interpretation of how disturbing they are, which almost certainly explains why 'The Haunted Tailor' is placed at the beginning of their selection (Howe \& Wisse 1979, pp.vii-ix, xxi, xxiv). Clearly, I am agreeing with Howe and Wisse in my reading. 
one. I am disgusted with the Israelis. ${ }^{3}$ Looking back now, I can't remember any particular moment when young that I decided to be anti-Zionist. I feel as if I have always known how profoundly wrong it was that Zionists came from Europe to brutally dispossess Palestine's indigenous people of their sovereign rights and install themselves in their place; and that Zionism in its nationalism and ethnic exclusiveness represents an historical assault on universalist traditions of Judaism, of internationalism and anti-racism, exemplified in radical Jewish traditions and in my own family. I feel as if I have always felt that these radical traditions have to reply to Zionist nationalism, have to reprise an honourable history (Docker 2012b, pp. 1-32; 2012c, pp. 241-284). Internationalism and anti-racism figure in both my mother and father's values, they are a dual legacy. In that sense, my parents' legacies have come together.

\section{References}

Arendt, H 2007, 'Walter Benjamin: 1892-1940', in W Benjamin, Illuminations, Schocken Books, New York, pp. 1-55.

Arendt, H 2006, Eichmann in Jerusalem: A report on the banality of evil, Penguin, London and New York.

Arendt, H, A Einstein, et al., 2007 'New Palestine Party: Visit of Menachem Begin and aims of political movement discussed', in J Kohn \& R H Feldman (eds), Hannah Arendt: The Jewish Writings, pp.417-419

Benjamin, W 2007, Illuminations, Schocken Books, New York.

Burgmann, V 1995, Revolutionary Industrial Unionism: The industrial workers of the world in Australia, Cambridge University Press, Cambridge.

Clark, K \& M Holquist 1984, Mikhail Bakhtin, Harvard University Press, Cambridge.

Curthoys, A 2012, 'Memory, History, and Ego-Histoire: Narrating and Reenacting the Australian Freedom Ride', Historical Reflections, vol. 38, no. 2.

Curthoys, N 2013, The Legacy of Liberal Judaism: Ernst Cassirer and Hannah Arendt's hidden conversation, Berghahn, New York.

3 My mother's letters to me in London are amongst the documents that Ann Curthoys and I have deposited in Mitchell Library; in late-2010 and early-2011 I spent some months reading our papers there. 
Docker, J 2013, 'Dissident Voices on the History of Palestine-Israel: Martin Buber and the bi-national Idea, Walid Khalidi's Indigenous perspective', in J Evans, A Genovese, A Reilly \& P Wolfe (eds), Sovereignty: Frontiers of possibility, University of Hawai'i Press, Honolulu, pp.86-116.

Docker, J 2012a, 'The Origins of Massacres', in P G Dwyer \& L Ryan (eds), Theatres of Violence: Massacre, mass killing and atrocity throughout history, Berghahn, New York, pp. 3-16.

Docker, J 2012b, 'Instrumentalising the Holocaust: Israel, settler-colonialism, genocide (creating a conversation between Raphaël Lemkin and Ilan Pappé)', Holy Land Studies, vol. 11, no. 1, pp. 1-32.

Docker, J 2012c, 'Orientalism and Zionism: Dismantling Leon Uris's Exodus', Arena Journal, New Series, no. 37-38, pp. 241-284.

Docker, J 2008a, 'Are Settler-Colonies Inherently Genocidal?: Re-reading Lemkin', in A Dirk Moses (ed.), Empire, Colony, Genocide: Conquest, occupation, and subaltern resistance in world history, Berghahn, New York, pp. 81-101.

Docker J 2008b, The Origins of Violence: Religion, history and genocide, Pluto Press, Melbourne.

Docker, J 2007, 'The Question of Europe: Said and Derrida', in N Curthoys \& D. Ganguly (eds), Edward Said: The legacy of a public intellectual, Melbourne University Press, Melbourne, pp. 263-290.

Docker, J 2001, 1492: The poetics of diaspora, Continuum, London.

Docker, J 1998, 'How Close Should Writers and Critics Be?', Australian Book Review no. 202, pp. 24-28.

Docker, J 1984a, 'Father and Son: From old left to new', Island Magazine, vol. 18-19, pp. 77-81.

Docker, J 1984b, In a Critical Condition: Reading Australian literature, Penguin, Sydney.

Docker, J 1981, 'How I Became a Teenage Leavisite and Lived to Tell the Tale', Meanjin, vol. 40, pp. 411-422.

Docker, J 1972, 'Sydney Intellectual History and Sydney Libertarianism', Politics, vol. 7, no. 1, pp. 40-47.

Docker, J \& A Curthoys 2006, Is History Fiction?, UNSW Press, Sydney.

Docker, T \& R Gerritsen 1976, 'The 1934 Kalgoorlie Riots', Labour History, no. 31 , pp. $78-82$. 
Ngapartji Ngapartji, In Turn, In Turn: Ego-histoire, Europe and Indigenous Australia

Ferrier, C 1999, Jean Devanny: Romantic revolutionary, Melbourne University Press, Melbourne.

Howe, I \& R R Wisse (eds) 1979, The Best of Sholom Aleichem, Weidenfeld and Nicolson, London.

Kohler, L (ed.) 1996, Within Four Walls: The Correspondence between Hannah Arendt and Heinrich Blücher, 1936-1968, Harcourt, New York.

Kohn, J \& R H Feldman (eds) 2007, Hannah Arendt: The Jewish writings, Schocken, New York.

Macintyre, S 1998, The Reds: The Communist Party of Australia from origins to illegality, Allen \& Unwin, Sydney.

Mendes-Flohr, P R 1983 (ed.), A Land of Two Peoples, Oxford University Press, New York.

Milner, L 2003, Fighting Films: A history of the Waterside Workers' Film Unit, Pluto Press, Melbourne.

Nora, P 2001, 'L'Ego-Histoire est-elle Possible?', Historein, vol. 3, pp. 19-26.

Prichard, K S 1984, Winged Seeds, Virago, London.

Rimbaud, A 2005, Complete Works, Selected Letters, translated by W Fowlie, University of Chicago Press, Chicago.

Sparrow, J 2007, Communism: A love story, Melbourne University Press, Melbourne.

Young-Bruehl, E 2004, Hannah Arendt: For love of the world, Yale University Press, New Haven.

Zertal, I 2011, Israel's Holocaust and the Politics of Nationhood, Cambridge University Press, New York.

Zukerman, W 1964, Voice of Dissent: Jewish problems, 1948-1961, Bookman Associates, New York.

Zukerman, W 1937, The Jew in Revolt: The modern Jew in the world crisis, Martin Secker and Warburg, London. 
This text taken from Ngapartji Ngpartji: In turn in turn:

Ego-histoire, Europe and Indigenous Australia

Edited by Vanessa Castejon, Anna Cole, Oliver Haag and Karen Hughes,

published 2014 by ANU Press, The Australian National University, Canberra, Australia. 